\title{
Road runoff and sediment sampling for determining road sediment yield at the watershed scale
}

\author{
Christopher G. Surfleet, Arne E. Skaugset III, and Matthew W. Meadows
}

\begin{abstract}
In this study, we demonstrate that watershed-scale estimates of road sediment production are improved if field measurements of road runoff and sediment production are used in the analysis. We used several techniques to spatially extrapolate measurements of road runoff and sampled sediment: comprehensive road runoff measurements, runoff estimates derived from the Distributed Hydrology Soil Vegetation Model (DHSVM), and adjustment of the road erosion models WARSEM and SEDMODL2.The sediment yield for the Oak Creek, Oregon, road network based on measured road runoff and sediment was 6.5 tons/year. When DHSVM was used to simulate road runoff, the estimated sediment from roads was similar, 6.9 tons/years. The road sediment production estimated by SEDMODL2 and WARSEM, adjusted with field-measured road runoff and sediment, was $28 \%$ and $34 \%$ less, respectively, than using the models with the default parameters. When applied to a road network in commercial forest land with frequent road use, the sediment yield estimated by SEDMODL2 and WARSEM without adjustment from field measurements was $480 \%$ and $610 \%$ higher, respectively, than with adjustments. We found that measuring runoff and sediment from one large storm event ( $\geq 1$ year recurrence) provided a statistically significant relationship with the annual sediment yield.

Résumé : Dans cette étude, nous démontrons que les estimations de production de sédiments associés aux chemins à l'échelle du bassin versant sont meilleures si des mesures de l'eau de ruissellement des chemins et de production de sédiments prises sur le terrain sont utilisées dans l'analyse. Nous avons utilisé plusieurs méthodes pour extrapoler dans l'espace les mesures de l'eau de ruissellement des chemins et des échantillons de sédiments : mesures détaillées de l'eau de ruissellement des chemins, estimations du ruissellement dérivées du modèle DHSVM («Distributed Hydrology Soil Vegetation Model ») et calibration des modèles d'érosion des chemins WARSEM et SEDMODL2. La production de sédiments associés au réseau routier d'Oak Creek, Oregon, basée sur des mesures de l'eau de ruissellement des chemins et des sédiments, était de 6,5 tons/an. Lorsque le modèle DHSVM était utilisé pour simuler le ruissellement, la quantité de sédiments associés aux chemins était semblable, soit 6,9 tons/an. La production de sédiments estimée par les modèles SEDMODL2 et WARSEM, calibrés avec les mesures de ruissellement et de sédiments prises sur le terrain, était respectivement $28 \%$ et $34 \%$ moins élevée que lorsque ces modèles étaient utilisés avec les paramètres implicites. Lorsqu'elle est appliquée à un réseau routier dans un territoire de forêt commerciale où les chemins sont fréquemment utilisés, l'estimation de la production de sédiments avec les modèles SEDMODL2 et WARSEM sans calibration avec les mesures prises sur le terrain était respectivement 480 $\%$ et $610 \%$ plus élevée comparativement aux résultats obtenus après calibration. Nous avons observé qu'il y avait une relation statistiquement significative entre les mesures de ruissellement et des sédiments associés à une grosse tempête (période de récurrence plus longue qu'un an) et la production annuelle de sédiments.
\end{abstract}

[Traduit par la Rédaction]

\section{Introduction}

A large amount of the sediment attributed to timber harvest activities is due to surface erosion from roads and road building (e.g., Reid 1981; Ketcheson and Megahan 1996). Increases in sediment production from timber harvest activities, which include forest roads, can degrade water quality and aquatic habitat (e.g., Spence et al. 1996; Haskell 2000; Gucinski et al. 2001). Concerns regarding the impacts of sediment due to timber harvest have resulted in regulations that require landowners to repair erosion sites, use improved har- vesting practices, and monitor reductions in sediment production. The implementation of forest policies has in many cases required landowners to accurately monitor reductions in erosion and the subsequent improvement of aquatic habitat over time.

Assessing sediment production from the erosion of forest roads is complex because of the many influences on the production and transport of erosion. The assessment becomes more complex in efforts to estimate sediment production from forest roads at a watershed scale. Watershed-scale amounts of sediment inputs from forest roads are commonly 
estimated from road erosion models. Common road surface erosion models used in forest watersheds are SEDMODL2, the Washington Road Surface Erosion Model (WARSEM), and WEPP:Road. These models have been widely used for a variety of objectives. For example, SEDMODL2 has been used as an evaluation tool in a model to decrease culvert spacing to assess sediment contributions (Damian 2001) as well as incorporated into haul routing evaluations (Krogstad and Schiess 2000) and road design and alignment evaluations (Akay and Sessions 2005). Both WARSEM and SEDMODL2 have been used in regulatory planning and decision making (LaPlante 2005) and monitoring of aquatic habitat conservation (Raines et al. 2005). WEPP:Road has been used by the US Forest Service and US Bureau of Land Management for assessment and planning (e.g., USDA Forest Service LTBMU 2006).

Models used to analyze road surface erosion can provide estimates of sediment production at a watershed scale or data that can help the user make those estimates. A crucial factor in the use of road erosion models is the accuracy of the model results. The assumption is that the models give a reasonable interpretation of the magnitude and spatial pattern of road sediment production. However, a lack of regional calibrations of model algorithms can lead to inaccurate model results (Sugden and Woods 2007). Further, without sitespecific data on the hydrologic response of roads, these models cannot be expected to provide accurate results for the variety of hydrologic responses that roads exhibit.

Overland flow is necessary to create surface erosion and transport detached soil from a road tread. Some road treads, the running surface of a road, or ditches draining a road can have infiltration capacities that exceed rainfall intensities and thus do not promote the overland flow necessary for surface erosion. Road cutslopes, the steepened slope adjacent to roads created from removing hillslope material while building roads, can intercept hillslope water, which can increase road runoff. However, in many areas, road cutslopes do not intercept hillslope water (e.g., Sugden and Woods 2007). The quantity of water running off roads is not necessarily a function of the road dimensions and associated precipitation (Luce 2002). Since surface erosion on roads requires surface runoff and the hydrologic responses of roads are not easily predicted, measurement of road runoff is an important approach in assessing road erosion.

The physical attributes of roads may not provide a reliable predictor of road hydrologic response; however, many physical attributes of roads do correlate with sediment loss. For example, roads with a native surface texture can have as much as 15-20 times the sediment production than a road with a competent rock surface (e.g., Reid 1981; Bilby et al. 1989;). Rutting of the road surface from vehicle traffic creates depressions where road runoff is concentrated, generating greater sediment loss (Foltz and Burroughs 1990; Toman and Skaugset 2011). As the slope of a road increases, the force of road runoff for detachment of surface material increases, producing greater sediment loss (e.g., Megahan and Ketcheson 1996; Luce and Black 1999; Sugden and Woods 2007). Vegetation cover of road cutslopes provides significant protection against sediment loss (Wischmeier and Smith 1960; Luce and Black 1999). External factors such as the amount of heavy vehicle traffic or intensity of precipitation further affect road sediment loss (Wischmeier and Smith 1960; Reid 1981; Bilby et al. 1989). Road inventories and field methods that identify physical factors such as these, that cause greater risk of sediment loss are important. However, the runoff of a road determines whether erosion will occur.

We propose that watershed-scale estimates of road sediment production will be improved if field-measured road runoff and sediment production are used in the analysis. Field measurements must be obtained by means of an appropriate sampling design to allow inference to watershed-scale estimates. Several different approaches could be used for the spatial extrapolation of road runoff and sediment production observed in the field. One approach would be to measure road runoff at all road locations in a watershed and then sample road sediment production at representative sites. Sediment production would be extrapolated to roads from the runoff and sediment load relationship developed for the watershed. However, measuring the runoff from all roads in a watershed is unrealistic, particularly for large watersheds. Another approach would be to use a hydrologic model that estimates road runoff in combination with the sediment-runoff relationship to provide spatial extrapolation of road sediment contribution. Yet another approach would be to adjust the parameters used in existing road erosion models such as SEDMODL2 and WARSEM based on field-sampled road runoff and sediment measurements and then use these adjusted models to spatially extrapolate sediment production estimates to the roads in the watershed.

This paper presents the results of road runoff and suspended sediment sampling from forest roads for Oak Creek watershed, Oregon. The road network in Oak Creek represents roads with low levels of use; the use is primarily light vehicles with infrequent heavy truck and equipment use. We used road runoff - sediment loss relationships in conjunction with road runoff measurements to estimate watershed-scale sediment losses. We also applied a hydrologic model and two road erosion models to also estimate watershed-scale sediment losses. We then applied our Oak Creek approach at the South Fork of the Albion River, California, a watershed with a road network used for commercial forest management, a road network representing a high level of heavy truck and equipment use. We additionally tested if grab suspended samples alone could provide a reasonable prediction of the magnitude or relative amount of road erosion from road segments.

\section{Study sites}

This study was conducted at Oak Creek, Oregon, with additional research at the South Fork of the Albion River, California. Oak Creek is located within the Oregon Coast Range approximately $4.5 \mathrm{~km}$ northwest of Corvallis, Oregon. Oak Creek is part of the McDonald/Dunn Forest owned and managed by the College of Forestry, Oregon State University. Average annual precipitation measured at Oak Creek from water years 2003-2007 was $970 \mathrm{~mm} /$ year with a range of 830-1110 $\mathrm{mm} /$ year. The bedrock underlying the watershed, the Siletz River Volcanics, is a basalt formation (Knezevich 1975). Soils in the watershed are classified as silty clay loam with some areas of silty loam (Knezevich 1975). Minor tim- 
ber harvest operations and low levels of heavy equipment use occur on the low-traffic roads in Oak Creek.

The South Fork of the Albion River is in a coastal watershed in western Mendocino County, California, approximately $200 \mathrm{~km}$ north of San Francisco, California. Rainfall is seasonal in this region, with most of the rain (approximately 1200-1400 mm/year) occurring between October and May. The South Fork of the Albion River is characterized by the Coastal Belt of the Franciscan Complex. The highly sheared rocks of the Coastal Belt are composed of structurally deformed, massive, hard greywacke sandstone and shale interbedded with small amounts of limestone and pebble conglomerate. Soils in the Coastal Belt are of the Inceptisol soil order with primarily silt loam and clay loam textures (Rittiman and Thorson 1993). The roads in the area of the South Fork of the Albion River are used for timber harvest operations. Road traffic throughout the road network varies from heavy to none depending on forest harvest timing and proximity.

\section{Methods}

\section{Road hydrology, turbidity, and suspended sediment measurements for Oak Creek}

From 2001 to 2007, all road drainage structures (114 culverts and road ditches) in Oak Creek were instrumented for collecting stage measurements to be used in calculating discharge based on a rating curve developed for the Oak Creek culverts. Stage measurements for the 23 stream-crossing culverts were recorded continuously by Tru-Track capacitance rods installed in trapezoidal flumes in the adjoining road ditches. Stage measurements for the 91 road drainage culverts were recorded at the inlets of the culverts by Tru-Track capacitance rods or crest gages that recorded peak stage measurements. Crest gages and capacitance rods were randomly placed among the 91 cross-drain culverts.

During the 2006 and 2007 water years, we used a turbidity threshold sampling (TTS) approach (Lewis 1996) to collect measurements of suspended sediment, turbidity, and road runoff at 17 road segments in the Oak Creek watershed. From the populations of road drainage culverts, we chose road segments for measurement based on a spatially balanced sample (Stevens and Olsen 2004). Oak Creek has relatively similar road design and level of road use across the watershed. Spatial variations in road response due to climate or hillslope hydrologic conditions were present, making a sample balanced across the watershed important.

The TTS monitoring stations had to be located at the outlets of culverts. This was to ensure that adequate water depth was available for submersion of the turbidity instrument. Because of this, no stream-crossing culverts could be used. The discharge from the outlet of stream-crossing culverts was not exclusively road runoff. The TTS monitoring station equipment consisted of a metal flume fitted with a Druck PDCR 1830 pressure transducer for discharge calculation, an OBS-3 turbidimeter from D\&A Instruments (now Campbell Scientific), a Campbell CR10-X data logger, and an ISCO 3700 automated water sampler for collecting suspended sediment samples. Turbidity and stage were measured continuously; suspended sediment samples were taken based on changes in incremental turbidity and discharge thresholds (Lewis and
Eads 2001). Monitoring took place for 1-2 months at each road segment during winter precipitation. The equipment was then moved to the next sites in the sample. In all, we monitored 17 road segments over the course of two winters. Continuous stage or crest gage measurements continued at the inlet of a culvert when the TTS equipment was removed.

We developed relationships between turbidity and suspended sediment according to storm or groups of storms during which four or more sediment samples were taken following the approach discussed in Lewis (1996). We used the continuous turbidity measurements with these relationships to calculate the storm sediment loads. We also developed sediment rating curves for each culvert to calculate the suspended sediment load for the remainder of winter storms without TTS monitoring.

For the culverts where we did TTS monitoring, we determined storm runoff volumes and peak flows for the 2006 and 2007 water years. We used linear regression to determine relationships between storm runoff volumes or peak flows and storm sediment load. We also used linear regression to determine relationships between storm peak flow and sediment load for culverts at which only crest gages had been placed. We calculated annual suspended sediment load for each road by summing the storm suspended sediment loads for each water year and then averaging the annual sediment loads for the two water years.

\section{Using measured road runoff and simulated runoff to estimate watershed-scale road sediment}

The sediment measured in the runoff from Oak Creek roads was suspended sediment (fine sediment). As a percentage of total sediment load in Oak Creek, sediment that quickly settled (coarse sediment) varied from $10 \%$ to $90 \%$ with a median value of $50 \%$ (Amann 2004). To obtain a representation of total sediment production from road surface erosion, we increased the suspended sediment load estimates generated from field measurements by $50 \%$.

We also simulated the road runoff to Oak Creek with the Distributed Hydrology Soil Vegetation Model (DHSVM) (DHSVM 2009) for the 2006 and 2007 water years. We obtained meteorological inputs to DHSVM from the meteorological station and precipitation gauges in the watershed. When meteorological inputs were missing from the Oak Creek station, we used measurements from the Corvallis Agrimet weather station, Corvallis, Oregon (maintained by the US Bureau of Reclamation). Soil inputs for DHSVM consisted of soil textures from the Benton County Soil Survey (Knezevich 1975). We calibrated DHSVM based on comparison with runoff results for the entire watershed (630 ha), two smaller watersheds (55 and 4 ha), and two road ditch observations ( $<1 \mathrm{ha})$. We used a systematic manual calibration approach similar to the technique from Whitaker et al. (2003). The calibration time period selected (October 2005 through summer 2006) showed the greatest variety of stream flow magnitudes and the largest events of the time period analyzed. We evaluated model fit to stream hydrographs quantitatively according to $(i)$ volume error for predicted versus observed runoff, (ii) model efficiency (Nash and Sutcliffe 1970), and (iii) coefficient of determination (D!) (Whitaker et al. 2003). Because it proved impossible to get good quantitative fits for the model output at the wide variety 
of scales used for the calibration, particularly the road runoff locations, we also qualitatively evaluated the general fit of model output to measured values. We used only the one calibrated parameter set for the road runoff simulation from DHSVM. We used the relationship between storm runoff volume and sediment load to calculate storm sediment loads for the DHSVM simulated road runoff to Oak Creek for the 2006 and 2007 water years.

\section{Road erosion model use}

We combined the sampled road runoff and sediment load measurements with two road erosion models to spatially extrapolate the sediment estimates to the watershed scale. The models were SEDMODL2, a GIS-based road erosion delivery model (NCASI 2002), and the Washington Road Surface Erosion Model (WARSEM), a database road erosion delivery model. Both models use the same calculations to estimate road surface erosion; the difference between the models is data input to the models. SEDMODL2 is an Arcinfo-based tool where many of the road attributes are developed from analysis of a digital elevation model. WARSEM is a spreadsheet model; we populated WARSEM with measurements from a road inventory. Detailed descriptions of SEDMODL2 and WARSEM can be found in technical documents provided from web pages maintained by the National Council of Air and Stream Improvement (NCASI 2002) and the Washington Department of Resources (2007), respectively.

In SEDMODL2 and WARSEM, total sediment delivered (in tons per year) from each road segment is calculated by the road tread plus the sediment delivered by the cutslope times a road age factor; both models incorporate a road age factor that increases the sediment delivery estimate if the road was built in the last 2 years: tread delivered sediment $=$ geologic erosion factor $\times$ tread surfacing factor $\times$ traffic factor $\times$ segment length $\times$ road width $\times$ road slope factor $\times$ rainfall factor $x$ delivery factor; and cutslope delivered sediment $=$ geologic erosion factor $\times$ cutslope cover factor $\times$ segment length $\times$ cutslope height $\times$ rainfall factor $\times$ delivery factor.

We used annual suspended sediment load estimates from the 17 roads measured in the Oak Creek watershed to calculate a combined geologic erosion factor, precipitation factor, and traffic factor within WARSEM and SEDMODL2. The geologic erosion factor represents the erosion rate based on the geology of the watershed; direct measurement of erosion from roads replaces this factor. The precipitation factor represents the hydrology affecting road erosion; the direct observation of road runoff replaces this factor. The traffic factor represents the amount of hauling and vehicle use on the road tread. We selected both inactive roads and roads on which recent hauling had occurred, thus capturing the range of traffic effects on road erosion for this watershed. This strategy allowed us to replace the traffic factor from the WARSEM and SEDMODL2 calculations with the road hydrology and sediment measurements for a watershed-scale estimate of road sediment production. The geologic erosion, precipitation, and traffic factors are multiplied in the model analysis; thus, they can be represented as one number.

For each of the road sites measured for runoff and suspended sediment, we adjusted a variable that represented the combined geologic erosion, precipitation, and traffic factors within SEDMODL2 and WARSEM until the model results equaled the annual sediment load determined for each road observed in the field. We then calculated a mean factor of geologic erosion, precipitation, and traffic for all 17 of the observed roads. We used the mean value of the geologic erosion, precipitation, and traffic factors in WARSEM and SEDMODL2 to calculate the sediment contribution for the Oak Creek watershed for the 2006 and 2007 water years. Using this approach, we adjusted the modeled sediment contribution by the percentage of coarse sediment to provide an estimate of total sediment production.

\section{Road hydrology and suspended sediment measurements for the South Fork of the Albion River, California}

In the watershed of the South Fork of the Albion River, we measured runoff and erosion yield for 22 road segments during the 2007 water year. We used a stratified random sample to select road segments from the population of road segments that deliver sediment to watercourses. We sampled six strata based on slope position (upper or lower half of the slope) and log hauling traffic (hauled or not hauled that year). We also sampled the main haul road exiting the watershed (both hauled and not hauled segments).

We collected road hydrologic measurements in low-cost circular flumes as described in Samani and Herrera (1996). The flumes were placed at locations where runoff left the road, either in the road ditch or at the outlet of a dip or erosion control feature. Stage was measured in the flumes by Odyssey water level recorders or crest gages. We collected suspended sediment samples at the flumes by hand during four winter storms. We calculated storm sediment load for each of the storms from sediment rating curves developed for individual road locations or aggregates of roads within sampled strata. We developed relationships between storm runoff volume and peak flow to storm sediment load for the different road strata and used these relationships to calculate the sediment loads for the storms without rating curve information.

The annual sediment load for each road segment was the sum of storm sediment loads. To represent total erosion yield for each road, we increased the total annual suspended sediment load by $67 \%$, the percentage of coarse particles from roads determined in an adjacent study (Barrett and Tomberlin 2007). We back-calculated geologic, traffic, and precipitation factors from the annual sediment loads measured and used within WARSEM and SEDMODL2 to spatially extrapolate the road erosion measurements to the watershed.

\section{Calculation of sample size}

We used the following power analysis to estimate the number of road sites at Oak Creek and the South Fork of the Albion River that might be monitored to reduce errors for watershed-scale sediment load estimates:

\section{[1] Number of road sites $=\left(Z_{\alpha / 2}\right)^{2} S^{2} / e^{2}$}

where $\left(Z_{\alpha / 2}\right)^{2}$ is the $Z$ statistic squared for a standard normal distribution with a two-tailed probability of $\alpha / 2, S^{2}$ is the variance of sediment load estimates, and $e^{2}$ is the acceptable error of the answer squared. 
Grab water samples for estimation of magnitude of road sediment load

\section{Estimating storm sediment load from grab water samples}

We used TTS measurements from the 17 Oak Creek road segments to determine if samples for suspended sediment concentration (SSC) alone could be related to storm sediment load. We used the SSC samples to represent random grab samples. To attempt to replicate the random collection timing, we randomly selected four, three, and two TTS samples per storm. We used linear regression to determine if there was a relationship between the mean of the randomly selected SSCs for each storm and storm sediment load. We also tested additional variables of storm peak flow and storm runoff volume to see if they improved the relationship.

We used linear regression to determine if there was a relationship between storm event sediment yield and the annual sediment yield from the road segments in Oak Creek during two large winter storms (the largest annual events), one in the 2006 water year and the other in the 2007 water year.

\section{Results}

\section{Relationship between storm volume or peak flow and storm sediment load}

For road drainage locations measured with TTS within Oak Creek for the 2006 and 2007 water years, the ratio of storm sediment load (tons) and storm runoff volume (litres) was $5.18 \times 10^{-9}$ with $95 \%$ confidence intervals of $2.328 \times$ $10^{-9}$ and $8.027 \times 10^{-9}\left(p<0.001\right.$, adjusted $\left.r^{2}=0.25\right)$ (Fig. 1a; eq. 2). The ratio of storm sediment load (tons) and storm peak flow (litres per second) was 0.0006 with $95 \%$ confidence intervals of 0.00029 and $0.00092(p<0.001$, adjusted $r^{2}=0.27$ ) (Fig. 1b; eq. 3). The resulting model explained only some of the variability in these relationships, as shown by low adjusted $r^{2}$ values of 0.25 and 0.27 :

[2 $\quad$ Storm sediment load (tons)

$$
=5.18 \times 10^{-9} \times \text { storm runoff volume }(\mathrm{L})-0.0004
$$

\section{[3 Storm sediment load (tons)}

$$
=0.0006 \times \text { storm peak flow }(\mathrm{L} / \mathrm{s})-0.0002
$$

Variability was high for the storm peak flow and runoff volume relationships with storm sediment loads in Oak Creek, which is common for sediment-runoff relationships. However, there were chronic soil failures at one road site used in this relationship. As a result, this road had much higher storm sediment loads than other roads (see outlier point in Figs. $1 a$ and $1 b$ ). If that one road is removed from the analysis, the relationships between storm volume or peak flow and storm sediment load remain statistically significant and the adjusted $r^{2}$ values increase to 0.5 and 0.52 , respectively. We chose not to remove the road from the sediment-runoff relationships used to predict sediment load from Oak Creek roads. The sediment measurements from this road represent a statistical outlier; however, problematic high-erosion sites occur on road networks in watersheds. A relationship that considers these high sediment delivery occurrences provides a more realistic estimate of the total sediment load for roads in a watershed.
Fig. 1. Relationship between suspended sediment load for the culverts with TTS measurements at Oak Creek and $(a)$ storm runoff volume and $(b)$ storm peak flow for the 2006 and 2007 water years.
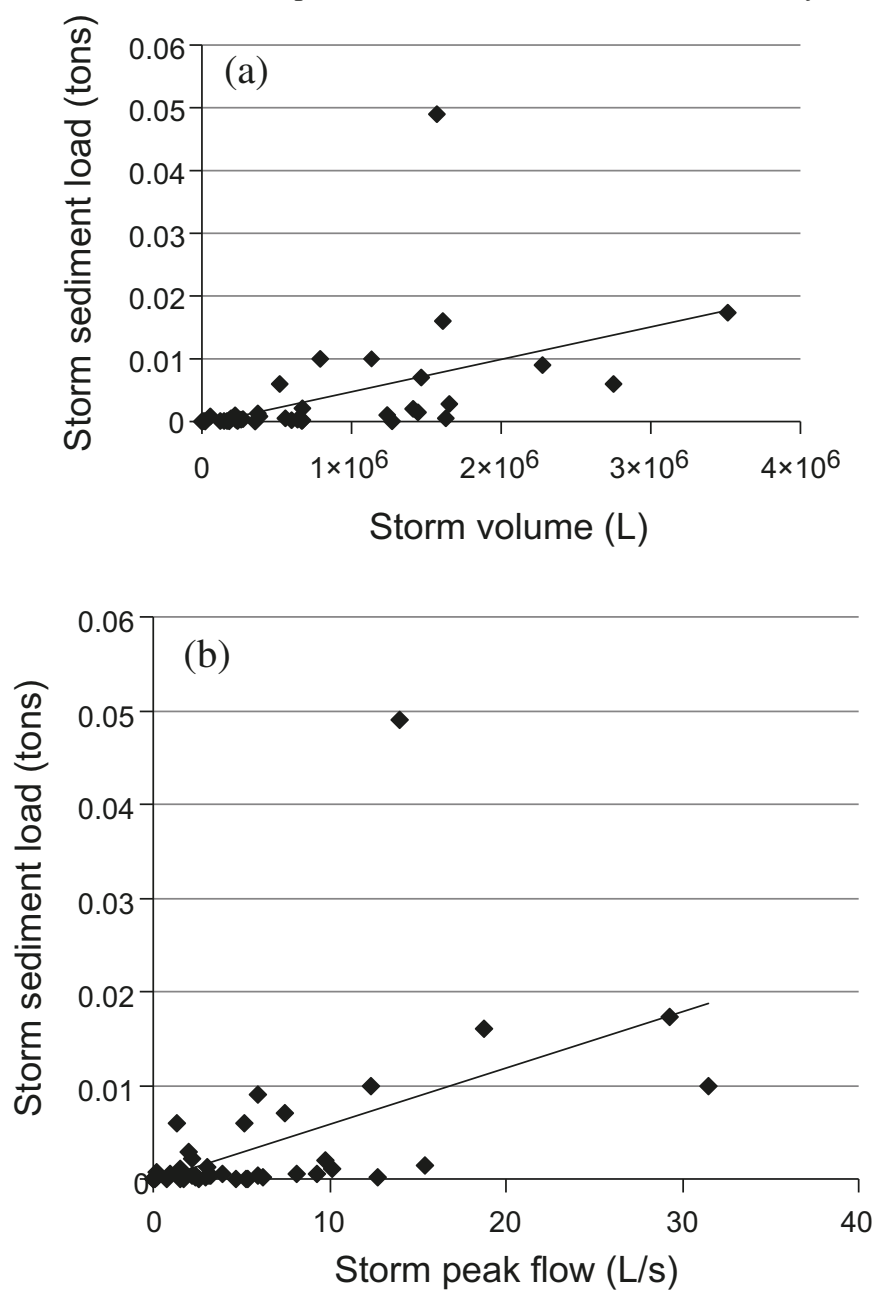

Road sediment estimates for Oak Creek

From the observed road runoff and the relationship of observed storm volume and storm suspended sediment load, adjusted to include coarse sediment, the watershed-scale estimate of sediment production from roads in the Oak Creek watershed was 6.2 tons/year with $95 \%$ confidence intervals of 4.5 and 7.8 tons/year. From the relationship of storm volume and storm suspended sediment load, with DHSVM simulated storm volume adjusted to include coarse sediment, the estimate of sediment production was 6.5 tons/year with $95 \%$ confidence intervals of 4.7 and 8.2 tons/year (Fig. 2).

For the 17 road segments in our Oak Creek study, the average product of the geologic erosion, precipitation, and traffic factors derived from field-measured sediment load was 2.7 ; the value suggested from the technical documentation (NCASI 2002) is 8 . With the 2.7 factor derived from field observations, SEDMODL2 estimated sediment delivery from roads of the Oak Creek watershed, with an adjusted increase for coarse sediment, at 9.1 tons/year and $95 \%$ confidence intervals of 8.1 and 10.0 tons/year (Fig. 2). With this same factor, WARSEM estimated sediment delivery, with an adjusted increase for coarse sediment, at 8.8 tons/year and 
Fig. 2. Comparison of total annual road sediment load for Oak Creek with SEDMODL2, WARSEM, observed road runoff, and DHSVM simulated road runoff for the 2006 and 2007 water years. Error bars can only be presented for models with field measurements where a variance for the inputs to the model could be calculated.

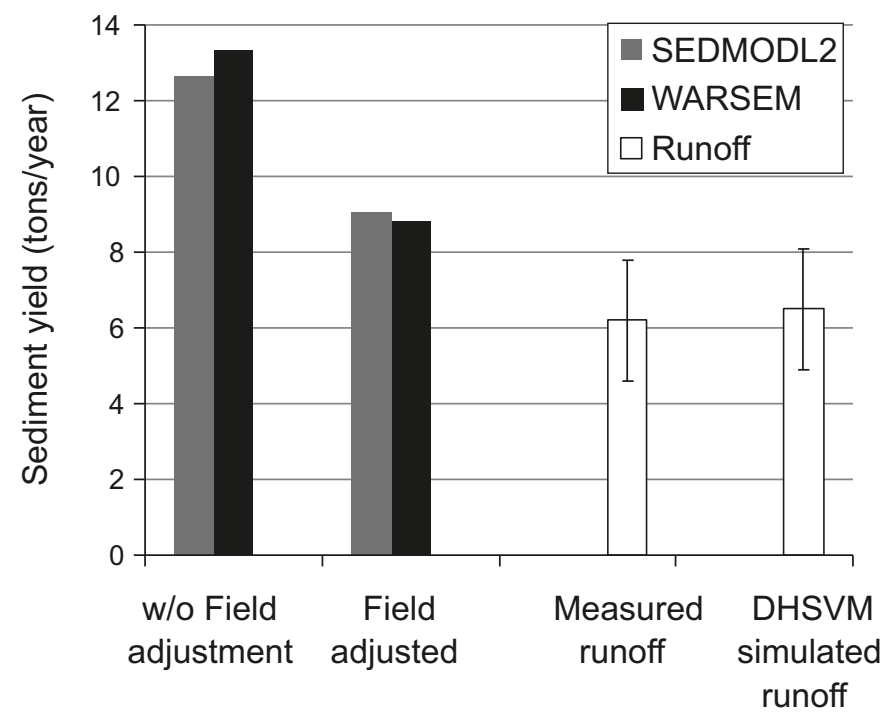

95\% confidence intervals of 8.0 and 9.7 tons/year (Fig. 2). With the factor of 8 suggested by the technical documentation (NCASI 2002), SEDMODL2 and WARSEM estimated average annual road sediment delivery at 12.7 and 13.3 tons/ year, respectively. A confidence interval is not available from the models using default parameters; only a single answer is provided.

\section{Road sediment estimates for the South Fork of the Albion River}

For all road sites monitored in the watershed of the South Fork of the Albion River, there was no statistically significant relationship between road runoff volume or peak flow and storm sediment load. However, when the roads were categorized into the six sampling strata, we observed relationships between storm volume or peak flow and storm sediment load. The relationships were not statistically significant because of the low number of measurements within each of the six sample strata. For the 22 road segments measured, the average product of the geologic erosion, precipitation, and traffic factors for use in SEDMODL2 and WARSEM was 1.16. The values for the models suggested by the technical documentation (NCASI 2002) varied between 11.2 and 56 depending on road traffic class. With the 1.16 factor calculated from the observed road sediment measurements, SEDMODL2 estimated sediment delivery for the 2007 water year, with an adjusted increase for coarse sediment, at 14.3 tons with $95 \%$ confidence intervals of 0.05 and 57.7 tons (Fig. 3). With the 1.16 factor, WARSEM estimated fine sediment delivery, with an adjusted increase for coarse sediment, at 18.0 tons with $95 \%$ confidence intervals of 0.06 and 69.8 tons. When the factors varied between 11.2 and 56, as suggested by the technical documentation (without field measurements; NCASI 2002), SEDMODL2 and WARSEM
Fig. 3. Road sediment load from SEDMODL2 and WARSEM for the South Fork of the Albion River for the 2007 water year. Error bars can only be presented for models with field measurements where a variance for the inputs to the model could be calculated.

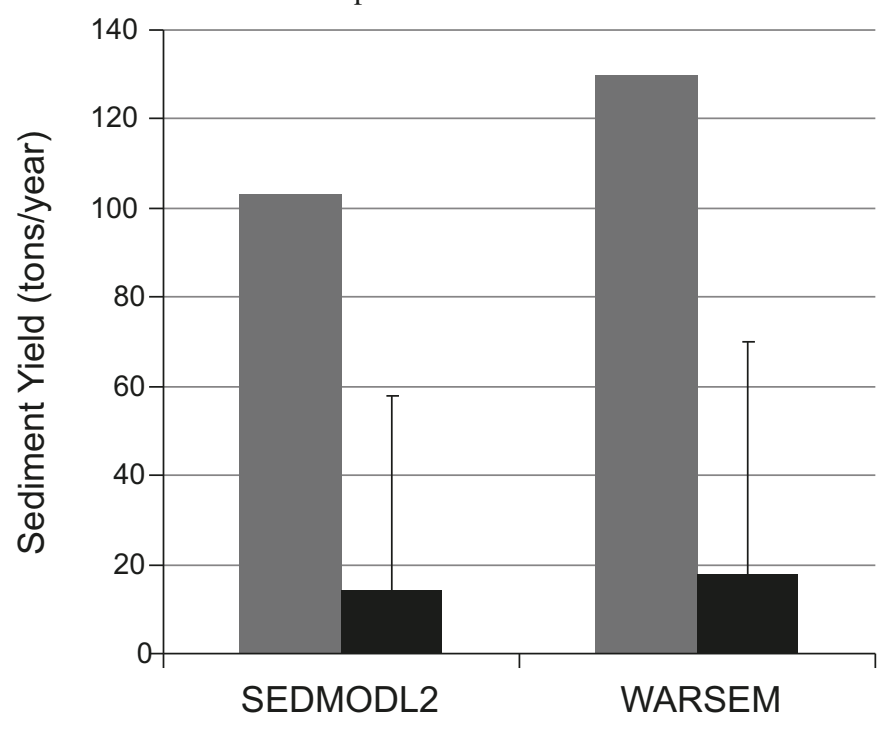

w/o field measurement adjustment

- Field measurement adjusted

estimated average annual road sediment delivery for roads of the South Fork of the Albion River watershed at 103.2 and 129.7 tons/year, respectively.

\section{Sample size estimate for watershed-scale road sediment measurement from road runoff}

Tables 1 and 2 present estimates, based on field measurements taken at Oak Creek and at the South Fork of the Albion River, of the numbers of road sites to be monitored for runoff and sediment measurements for estimation of storm sediment loads with confidence level and error. These results represent not only a consideration of the confidence in the results $(\alpha)$ to not have a type I error (a false positive of a tested hypothesis) but also consider the error $(\beta)$ to avoid a type II error (a false negative of a tested hypothesis). Comparing the sample sizes calculated from estimated road sediment loads from Oak Creek and South Fork of the Albion River, much fewer samples are needed in a watershed like Oak Creek, with uniform low traffic roads, using a TTS approach for road runoff and sediment load estimation.

\section{Grab suspended sediment samples for estimation of the magnitude of road sediment load}

The ratio of storm sediment load (tons) and the mean of four randomly selected SSC samples (milligrams per litre) from individual storms was 0.0001 with $95 \%$ confidence intervals of 0.00005 and 0.00015 ( $p=0.01$, adjusted $r^{2}=$ 0.19) (Fig. 4; eq. 4). The resulting model explained little of the variability in the relationship, as shown by a low adjusted $r^{2}$ of 0.19 . There was no statistically significant relationship between the mean of either three or two randomly selected suspended samples from a storm and the storm sediment load at the $95 \%$ confidence level with $p$ values of 0.07 and 0.84 , respectively: 
Table 1. Number of road sites to be sampled, based on error and confidence level, by the turbidity threshold sampling and road sampling scheme used at Oak Creek.

\begin{tabular}{llll}
\hline & \multicolumn{4}{l}{ Number of road sites by confidence level $(\alpha)$} \\
\cline { 2 - 4 } Error $(\beta)$ & $90 \%$ confidence & $95 \%$ confidence & $99 \%$ confidence \\
\hline $1 \%$ & 13 & 18 & 21 \\
$5 \%$ & 1 & 1 & 1 \\
\hline
\end{tabular}

Table 2. Number of road sites to be sampled, based on error and confidence level, by the lowtechnology approach of sediment sampling used at the South Fork of the Albion River.

\begin{tabular}{cccc}
\hline & \multicolumn{4}{l}{ Number of road sites by confidence level $(\alpha)$} \\
\cline { 2 - 4 } Error $(\beta)$ & $90 \%$ confidence & $95 \%$ confidence & $99 \%$ confidence \\
\hline $1 \%$ & 10620 & 15000 & 20600 \\
$5 \%$ & 425 & 600 & 825 \\
$10 \%$ & 110 & 150 & 210 \\
$20 \%$ & 26 & 37 & 52 \\
\hline
\end{tabular}

Fig. 4. Relationship between the mean of four randomly selected suspended sediment samples and suspended sediment load for storms at Oak Creek for the 2006 and 2007 water years.

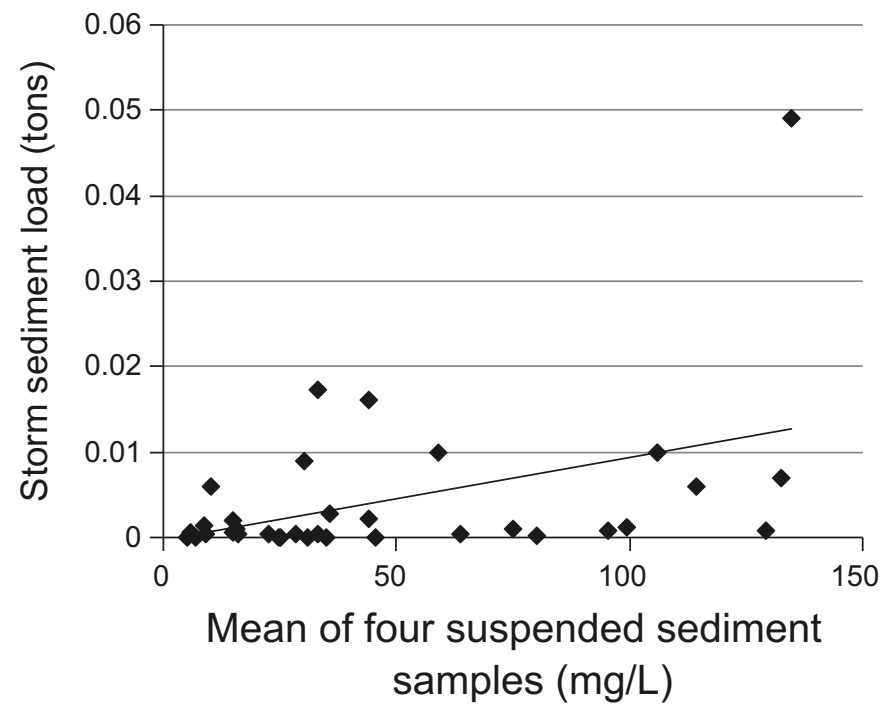

[4 Storm sediment load (tons)

$=0.0001 \times$ mean of four SSC samples $(\mathrm{mg} / \mathrm{L})-0.0003$

Multiple linear regression showed that including the peak flow value in a model with four randomly selected sediment samples explained more of the variability for the storm sediment load estimate. We found a statistically significant relationship for the estimate of the natural log of the storm sediment load by combining the mean of four randomly suspended sediment samples and the storm peak flow $(p<0.02$, adjusted $r^{2}=0.47$ ) (eq. 5). Evidence was not sufficient to show that including storm volume (instead of peak flows) provided a better model for the sediment load estimates than using only four randomly selected sediment samples $(p<$ $0.001)$ :

[5 Storm sediment load (tons)

$$
\begin{array}{r}
=0.0001 \times \text { mean of four SSC samples }(\mathrm{mg} / \mathrm{L}) \\
+0.0006 \times \text { peak flow }(\mathrm{L} / \mathrm{s})-0.0032
\end{array}
$$

We observed a statistically significant relationship between road storm sediment load and the total annual road sediment load for the 2006 (Fig. 5a; eq. 6) and 2007 (Fig. 5b; eq. 7) water years (WY) $\left(p<0.0001\right.$ for both relationships, $r^{2}=$ 0.86 and 0.77 , respectively):

[6 2006 WY annual sediment load (tons)

$=9.27 \times$ large storm sediment load (tons) -0.004

[7 2007 WY annual sediment load (tons)

$=7.94 \times$ large storm sediment load (tons) -0.006

\section{Discussion}

\section{Sediment yield estimates for roads}

The road sediment yield for the 2006 and 2007 water years varied according to the technique used to quantify it. When modeled by SEDMODL2 and WARSEM, estimates of total annual road sediment production for Oak Creek were $40 \%$ and $51 \%$ higher, respectively, without adjustment from field measurements than with adjustments. At the South Fork of the Albion River, the sediment yields estimated by SEDMODL2 and WARSEM without adjustment from field measurements were $480 \%$ and $610 \%$ higher, respectively, than with adjustments.

WARSEM and SEDMODL2 provide estimates interpreted as long-term averages of erosion from roads. Average erosion over many years, with both wet and dry years, is assumed in the WARSEM and SEDMODL2 estimates. For this study, the field-measured sediment yield was for two water years for Oak Creek and one water year for the South Fork of the Albion River. The South Fork of the Albion River received 32 inches of rain, well below the average annual rainfall of 50 inches. At Oak Creek, annual rainfall for the 2006 and 2007 water years was about average, but several large storms ( $>1$ year recurrence interval) occurred during the 2006 water year. The large storms of 2006 used for the Oak Creek analysis probably make the comparison of results between the modeled and measured sediment estimates reasonable. However, the year of low precipitation for the South Fork of the Albion River partly explains why WARSEM and SED- 
Fig. 5. Relationship between storm sediment load and total annual sediment load for road suspended sediment Oak Creek for $(a)$ one storm in the 2006 water year and $(b)$ one storm in the 2007 water year.
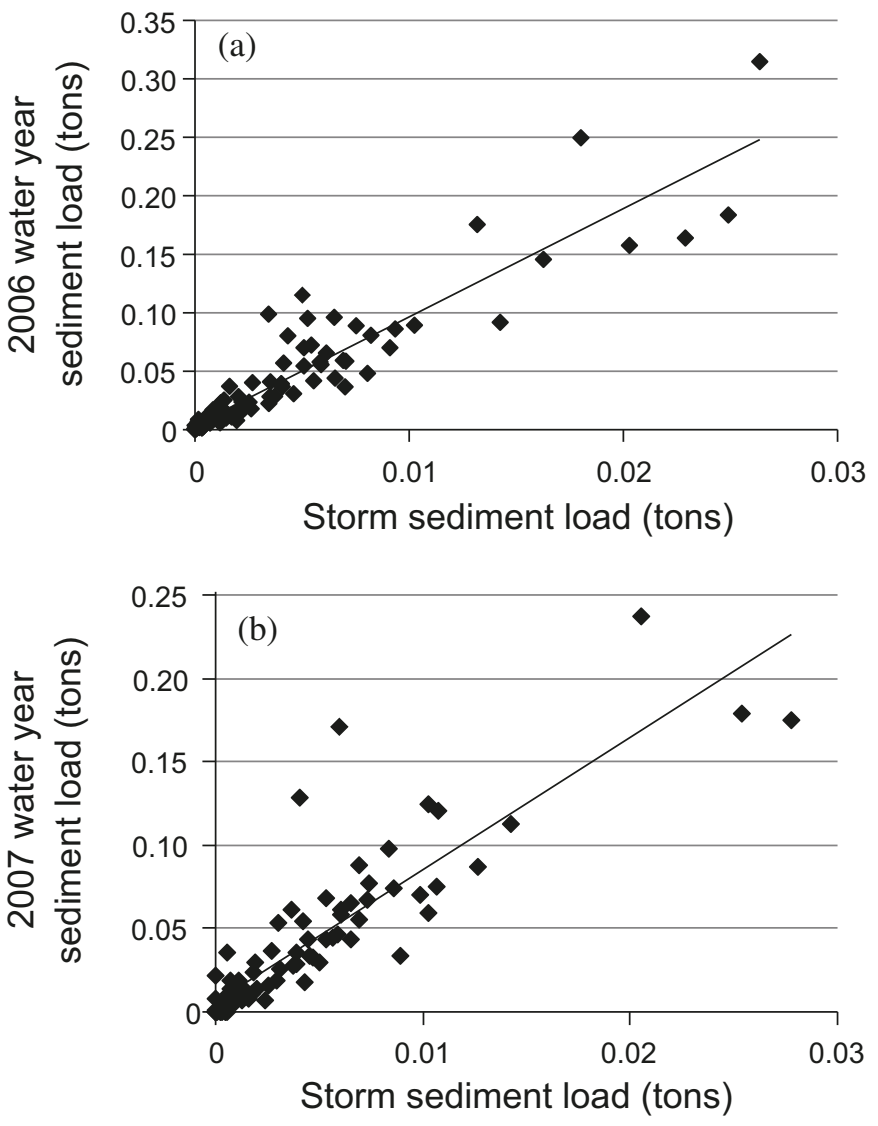

MODL2, without adjustments for field measurements, overestimated the sediment yield. However, the difference in estimated sediment yields is so large that we concluded that model inputs in addition to low rainfall contributed to errors.

\section{Road hydrologic response and sediment yield}

The relationship between storm peak flow or runoff volume and storm sediment load demonstrated that road runoff measurements can be used for estimating sediment production from roads. Forest road runoff is highly variable. Some roads exhibit infiltration excess overland flow from the road surface, some roads intercept significant amounts of hillslope water, while other roads do not, and many roads have road treads with high infiltration capacity that have little to no runoff. Almost all road surface erosion models rely heavily on measurements of the physical attributes of a road. Physical attributes such as road surface type, surface ruts, traffic on the road, gradient of the road, length of the road segment, or vegetation cover on road cut- and fill-slopes are related to road erosion (e.g., Reid 1981; Bilby et al. 1989; Luce and Black 1999). Yet the amount of runoff on the road influences how these physical attributes affect erosion. If a road with high erosion potential, as predicted by its physical features, has no runoff, then no erosion will occur. Similarly, a road with low erosion potential yet very high runoff could have considerable erosion. Given the uncertainties associated with using the physical attributes of a road to estimate hydrologic response, developing techniques for predicting or observing road hydrologic response used in conjunction with inventories of road physical features would $(i)$ enable more accurate estimates of road sediment yield and (ii) provide more accurate indications of the magnitude of sediment delivery from individual road locations.

In this study, we used the hydrologic model DHSVM to estimate road hydrologic response for the Oak Creek roads. We estimated sediment yield by means of the storm volume to sediment load relationship for the simulated road runoff from DHSVM. The 95\% confidence interval of total annual road sediment load estimated from DHSVM simulated road runoff was 4.7-8.2 tons/year. This result was closer to the sediment estimate produced from the actual road runoff measurements than the estimates produced from SEDMODL2 and WARSEM adjusted by field measurements.

At Oak Creek, DHSVM performed poorly at simulating site-specific effects from roads, but at the watershed scale, DHSVM simulated the hydrologic response from roads well (Surfleet et al. 2010). This result suggests that a hydrologic model that estimates road response in conjunction with a road runoff and sediment sampling scheme could be useful in quantifying the watershed-scale production of road-associated sediment. However, the watershed size must be large enough for the hydrologic model to accurately quantify the volume of road runoff. Given the uncertainties seen in DHSVM predictions of individual road locations (Surfleet et al. 2010), DHSVM may not provide accurate quantification of the magnitude of sediment production for individual road sites.

The relationships determined at Oak Creek between sediment load and storm volume or peak flow were also observed at the South Fork of the Albion River. However, we had to develop the relationships by the road sample stratification class because of variability in road design and hydrologic response throughout the watershed. At the South Fork of the Albion River, these relationships were not statistically significant because of the few data points used. We also observed the linear relationship between road runoff and sediment load, but again, it had no statistical significance. In watersheds with a variety of road designs, road uses, geology, soils, and precipitation, these variations must be considered in efforts to determine the relationships between road runoff and sediment load.

\section{Reducing uncertainty for estimates of road sediment production}

At Oak Creek, the TTS approach for measuring road sediment and turbidity, combined with continuous measurement of road runoff, provided estimates of sediment yield with low variance. At the South Fork of the Albion River, we did not monitor road runoff continuously throughout the winter and we collected road sediment measurements at varying times throughout a few storm events. This approach provided a sediment yield estimate with high variance. Achieving comparable precision in results, at a $95 \%$ confidence interval within a $1 \%$ margin of error, would require 18 roads to be sampled via the Oak Creek TTS approach but 15000 roads with the approach used at the South Fork of the Albion River. Continuous measurements of road runoff throughout a winter, along with sampling techniques that provide accurate 
measurement of sediment and turbidity, would provide considerable reduction in uncertainty of estimates of road sediment production.

The sediment load estimated by SEDMODL2, adjusted by field measurements, for the South Fork of the Albion River resulted in a wide 95\% confidence interval (0.05-57.7 tons/ year), a range of close to $700 \%$ of the estimate of 14.3 tons/ year. Most sediment budget calculations accept an order of magnitude margin of error; a range of $700 \%$ would be within this range. However, to discern long-term changes in sediment delivery trends from forest roads, a range of $700 \%$ in the confidence interval is probably too high. The number of roads suggested for measurement to achieve a 95\% confidence interval within a $10 \%$ margin of error, as calculated from results at the South Fork of the Albion River, was 150. Because an average annual sediment yield is desired, roads do not have to be measured in the same year. The effort could be spread over several consecutive years to represent the road sediment contributions for that time frame. This strategy would provide a greater number of road sediment delivery locations for monitoring, spanning many storm events, and thus reduce uncertainty in the watershed's road sediment estimates.

To measure a greater number of roads at the South Fork of the Albion River, throughout the winter, we moved the flumes and the 12 capacitance rods that were measuring road runoff. At Oak Creek, we moved the TTS system throughout the winter, but road runoff measurement equipment remained in place. Moving the road runoff equipment at the South Fork of the Albion River necessitated extrapolating hydrologic responses from one road to another based on the relationship between sites, which introduced error, increasing the variance of the estimates. The most accurate storm sediment load estimates are those generated from actual hydrologic measurements of road runoff for the storm being estimated. To reduce uncertainty in road sediment estimates, hydrologic measurements throughout the entire winter at selected road locations should be used. The hydrologic measurements are necessary to allow the extrapolation of sediment and discharge relationships to other storms. Continuous observation of discharge at road sites is preferable, but crest gages that provide the peak flow can be useful for a subset of road sites.

The number of sediment samples used to determine sediment rating curves influences the variance of sediment load estimates. Using a turbidity and sediment sampling scheme such as TTS ensures adequate samples for reduction in variance of sediment load estimates. Using grab samples, taken by hand during storms, to develop sediment rating curve will be less accurate and result in a higher variance for sediment load relationships; this increases the uncertainty in sediment yield estimates. Increasing the number of grab samples per storm will reduce this uncertainty, but at the trade-off of a considerable effort of labor.

\section{Storm sampling for magnitude of road sediment production}

The road sediment load for the two large storms sampled in 2006 and 2007, respectively, had a linear relationship with the corresponding annual sediment yield from those roads. This suggests that a road sediment sampling approach with the objective of quantifying the sediment load for a single large storm would provide enough information to describe the magnitude of sediment delivery from roads in a watershed for at least that year if not longer.

At Oak Creek, $50 \%$ of the annual sediment delivery came from 13 road segments out of a total of 94 road segments. From a management perspective, that result might be more important than accurate quantification of watershed-scale sediment delivery. An approach whereby one grab sample is taken from each road site would not approximate the storm sediment load magnitude from a site. At Oak Creek, we found that at least four grab suspended sediment samples had to be taken throughout a storm event to correlate with the road's storm sediment load. Admittedly, the relationship between four suspended sediment samples and storm sediment load is weak $\left(r^{2}=0.19\right)$, but it is statistically different from zero. This suggests that taking at least four suspended sediment samples of road runoff from large storm events can be used to determine the magnitude of road sediment contributions, if not the actual quantity.

\section{Conclusions}

This study demonstrated that field measurements of road runoff and sediment load from roads improved estimates of road sediment production at a watershed scale. Field measurements of road runoff and suspended sediment were used to adjust the hydrologic, geologic, and traffic hazard factors in the road erosion models WARSEM and SEDMODL2. The adjusted WARSEM and SEDMODL2 models improved watershed-scale estimates of road sediment delivery. This demonstrated that not only is model calibration important but the use of road runoff combined with physical attributes of roads that influence erosion provides a more accurate approach to evaluation of road sediment production. The importance of road runoff for road sediment estimates was shown in Oak Creek, a watershed with a uniform road design and level of road use. The estimates of road sediment yield from measured road runoff were similar but slightly lower than estimates from WARSEM and SEDMODL2 adjusted with field measurements. When the sediment yield from roads was estimated with simulated road runoff from a hydrologic model, DHSVM, the result was similar to the sediment yield estimated from observed road runoff.

A sampling approach in which sediment loads from roads during a large storm were quantified provided a linear relationship with the annual sediment yield from those roads. We found a statistically significant relationship with four grab suspended samples and a road's storm sediment load. These findings suggest that a road sediment sampling approach that has the objective of quantifying the sediment load for a single large storm with only grab suspended sediment samples could provide information that would help describe at least the magnitude of sediment delivery from individual road locations in a watershed.

A tremendous amount of resources are spent on inventorying roads for prioritization of road sediment control or monitoring of road sediment production. Yet, road inventories alone may not accurately predict the response that they intend to measure. An approach where the runoff of roads is considered along with the physical features and conditions of the roads will address the processes that affect road sediment 
production. Indeed, the measurement of road runoff may be the more important variable to measure for determining road sediment production.

\section{Acknowledgments}

This work was made possible by grants from the National Council of Air and Stream Improvement, Oregon Timber Tax Fish and Wildlife funds, and Center for Wood Utilization funds from the Department of Forest Engineering, Oregon State University. Access to the South Fork of the Albion River, equipment, and travel expenses were provided by the Mendocino Redwood Company, LLC. The L.L. Stewart Graduate Fellowship provided financial support for Christopher Surfleet. Kirk Vodopals provided field assistance and was the liaison for support from the Mendocino Redwood Company. We also thank Elizabeth Toman, Amy Simmons, Nicolas Zegre, Kelly Kibler, Tim Royer, and Tim Otis, who provided technical assistance and assisted with collection of synoptic samples.

\section{References}

Akay, A., and Sessions, J. 2005. Applying the decision support system, TRACER, to forest road design. West. J. Appl. For. 20: 184-191.

Amann, J. 2004. Sediment production from roads in the upper Oak Creek watershed of the Oregon Coast Range. M.Sc. thesis, Forest Engineering Department, Oregon State University, Corvallis, Ore.

Barrett, B., and Tomberlin, D. 2007. Sediment production on forest road surfaces in California's Redwood Region: results for Hydrologic Year 2005-2006. In Proceedings of the Society of American Foresters Annual Meeting, 2007. Society of American Foresters, Portland, Ore.

Bilby, R.E., Sullivan, K., and Duncan, S.H. 1989. The generation and fate of road-surface erosion in forested watersheds in southwestern Washington. For. Sci. 35(2): 453-468.

Damian, F. 2001. Improving cross drain culvert spacing with GIS interactive design tool. In Proceedings of the International Mountain Logging and 11th Pacific Northwest Skyline Symposium, Seattle, Wash. pp. 201-206. Available from http://depts. washington.edu/sky2001/ [accessed 16 September 2011].

DHSVM. 2009. Web site for the Distributive Hydrology Soil Vegetation Model. Available from http://www.hydro.washington. edu/Lettenmaier/Models/DHSVM/index.shtml [accessed 30 September 2009].

Foltz, R., and Burroughs, E.R. 1990. Sediment production from forest roads with wheel ruts. In Proceedings: Watershed Planning and Analysis in Action. Edited by R.E. Riggins et al. American Society of Civil Engineers, New York. pp. 266-275.

Gucinski, H., Furniss, M., Ziemer, R., and Brookes, M. 2001. Forest roads: a synthesis of scientific information. U.S. For. Serv. Gen. Tech. Rep. PNW-GTR-509.

Haskell, D.G. 2000. Effects of forest roads on macroinvertebrate soil fauna of the southern Appalachian Mountains. Conserv. Biol. 14 (1): 57-63. doi:10.1046/j.1523-1739.2000.99232.x.

Ketcheson, G., and Megahan, W. 1996. Sediment production and downslope sediment transport from forest roads in granitic watersheds. U.S. For. Serv. Res. Pap. INT-RP-486.

Knezevich, C.A. 1975. Soil survey of Benton County area, Oregon. U.S. Department of Agriculture, Soil Conservation Service, in cooperation with the Oregon Agricultural Experiment Station. U.S. Government Printing Office, Washington, D.C.

Krogstad, F., and Schiess, P. 2000. Haul routing: an overlooked factor in environmental driven road decommissioning. In Technologies for New Millennium Forestry: Proceedings of the 23rd Annual Meeting of the Council on Forest Engineering. Council of Forest Engineering, Kelowna, B.C.

LaPlante, D. 2005. A geodatabase system for TMDL sediment production analysis. In Proceedings of the 25th Annual ESRI User Conference (Editors). ESRI, San Diego, Calif.

Lewis, J. 1996. Turbidity-controlled suspended sediment sampling for runoff-event load estimation. Water Resour. Res. 32(7): 2299_ 2310. doi:10.1029/96WR00991.

Lewis, J., and Eads, R. 2001. Turbidity threshold sampling for suspended sediment load estimation. In Proceedings of the Seventh Federal Interagency Sedimentation Conference, 25-29 March 2001. The Federal Subcommittee on Sedimentation, Reno, Nev. pp. III-110-III-117.

Luce, C.H. 2002. Hydrological processes and pathways affected by forest roads: what do we still need to learn? Hydrol. Process. 16 (14): 2901-2904. doi:10.1002/hyp.5061.

Luce, C.H., and Black, T.A. 1999. Sediment production from forest roads in western Oregon. Water Resour. Res. 35(8): 2561-2570. doi:10.1029/1999WR900135.

Megahan, W.F., and Ketcheson, G.L. 1996. Predicting downslope travel of granitic sediments from forest roads in Idaho. Water Resour. Bull. 32(2): 371-382. doi:10.1111/j.1752-1688.1996. tb03459.x.

Nash, J.E., and Sutcliffe, J.V. 1970. River flow forecasting through conceptual models part 1 - A discussion of principles. J. Hydrol. (Amst.), 10(3): 282-290. doi:10.1016/0022-1694(70)90255-6.

NCASI. 2002. Technical documentation for SEDMODL version 2.0 road erosion/delivery model. Downloadable from the NCASI website: http://www.ncasi.org/support/downloads/Detail.aspx? $\mathrm{id}=5$ [accessed 14 October 2009].

Raines, M., Conrad, R., Clark, J., Coe, D., Palmquist, R., and Veldhuisen, C. 2005. Road sub-basin scale effectiveness monitoring design. Study plan. Department of Natural Resources, Olympia, Wash.

Reid, L.M. 1981. Sediment production from gravel-surfaced forest roads, Clearwater basin, Washington. FRI-UW-8108. Fisheries Research Institute, University of Washington, Seattle.

Rittiman, C.A., and Thorson, T. 1993. Soil survey of Mendocino County, California, western part. U.S. Department of Agriculture, Natural Resources Conservation Service, in cooperation with the California Department of Forestry, Soil Vegetation Survey; Georgia-Pacific Corporation; the Regents of the University of California (Agricultural Experiment Station); and the United States Department of the Interior, Bureau of Land Management. Published online at http://www.ca.nrcs.usda.gov/mlra02/wmendo/

Samani, Z., and Herrera, E. 1996. A low-cost water measuring device. Guide M-226:PH-4-205. New Mexico State University Cooperative Extension Service, Las Cruces, N.M.

Spence, B., Lomnicky, G., Hughes, R., and Novitzki, R. 1996. An ecosystem approach to salmonid conservation. Report TR-450196-6047. Mantech Environmental Technology, Inc., Corvallis, Ore.

Stevens, D., Jr, and Olsen, A. 2004. Spatially balanced sampling of natural resources. J. Am. Stat. Assoc. 99(465): 262-278. doi:10. 1198/016214504000000250.

Sugden, B.D., and Woods, S.W. 2007. Sediment production from forest roads in western Montana. J. Am. Water Resour. Assoc. 43 (1): 193-206. doi:10.1111/j.1752-1688.2007.00016.x.

Surfleet, C., Skaugset, A., and McDonnell, J. 2010. Uncertainty assessment of forest road modeling with the Distributed Hydrology Soil Vegetation Model (DHSVM). Can. J. For. Res. 40(7): 1397-1409. doi:10.1139/X10-079. 
Toman, E.M., and Skaugset, A.E. 2011. Reducing sediment production from forest roads during wet-weather hauling. J. Transportation Res. Board, 1(2203): 13-19.

USDA Forest Service LTBMU. 2006. 2005/2006 Monitoring program annual report. USDA Forest Service LTBMU, Lake Tahoe, Calif.

Washington Department of Resources. 2007. Web citation for Washington road surface erosion model (WARSEM): http:// www.dnr.wa.gov/BusinessPermits/Topics/ForestPracticesApplications/Pages/fp_warsem.aspx [accessed 16 September 2011].
Whitaker, A., Alila, Y., Beckers, J., and Toews, D. 2003. Application of the distributed hydrology soil vegetation model to Redfish Creek, British Columbia: model evaluation using internal catchment data. Hydrol. Precesses, 17(2): 199-224. doi:10.1002/hyp. 1119.

Wischmeier, W.H., and Smith, D.D. 1960. A universal soil loss equation to guide conservation farm planning. Transactions of the 7th International Congress of Soil Science. Vol. 1. International Society of Soil Science, Madison, Wis. pp. 418-425. 